Engineered MOFs and Enzymes for the Synthesis of Active Pharmaceutical Ingredients

Francisco G. Cirujano*[a]
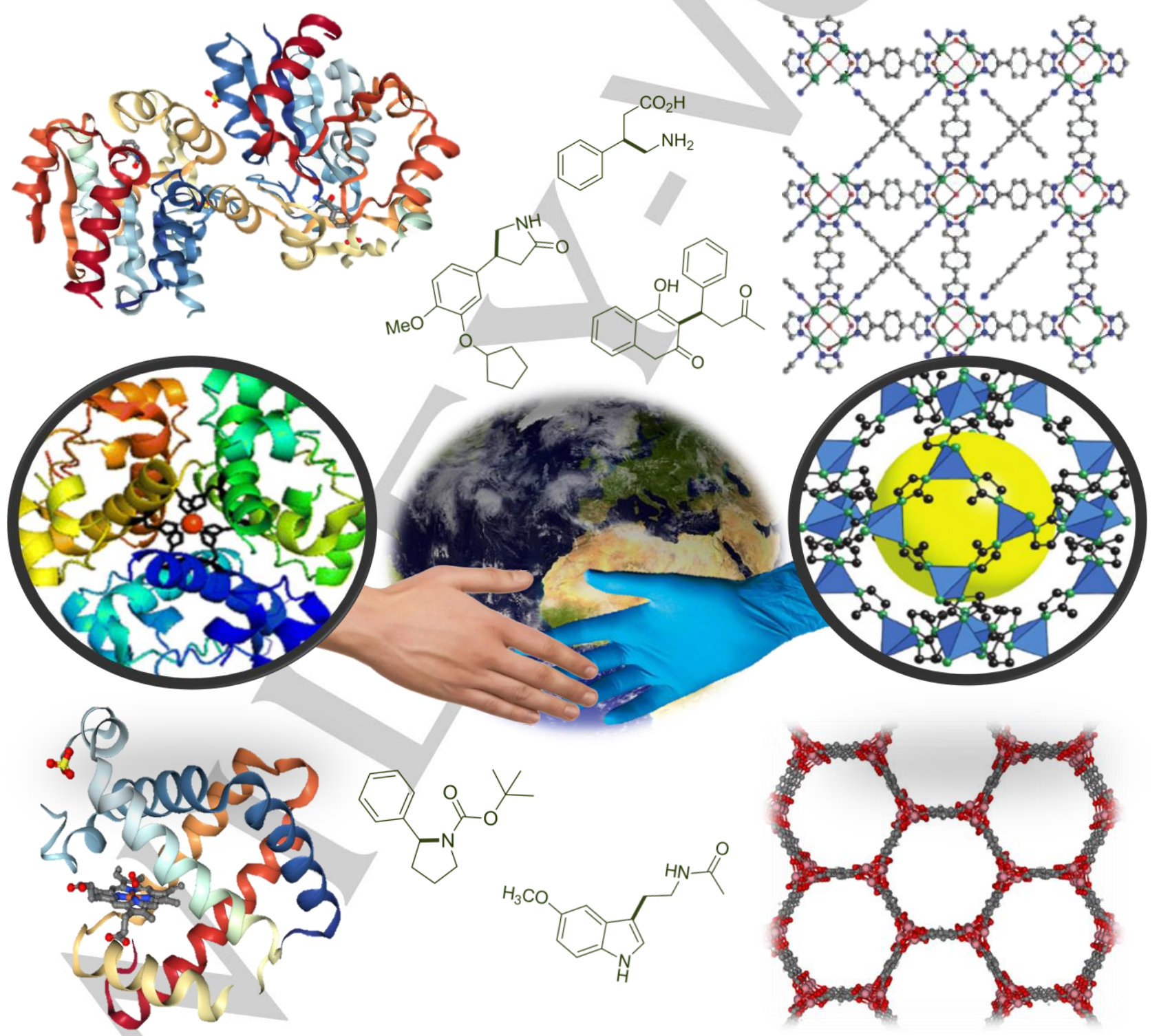


\section{Engineered MOFs and Enzymes for the Synthesis of Active Pharmaceutical Ingredients}

\author{
Francisco G. Cirujano*[a]
}

The latest strategies in the design and synthesis of metalorganic frameworks as heterogeneous catalysts in organic synthesis are compared with biocatalyzed transformations, as a step forward to a more convenient industrial production of pharmaceuticals. Relevant $\mathrm{C}-\mathrm{C}$ and $\mathrm{C}-\mathrm{N}$ bond forming reactions that are both chemo- and bio- catalyzed by synthetic MOFs and in vitro evolved and/or promiscuous enzymes with the aim of obtaining key bioactive scaffolds in a sustainable, competitive and cost-efficient manner, are thoroughly discussed in this mini review.

\section{Introduction}

Pharmaceuticals successfully employed to fight degenerative diseases, immune disorder, infection, cancer or pain have played a fundamental role in the life expectancy increase during the last decades. ${ }^{[1]}$ The main components of these approved drugs are usually produced through multiple organic synthesis and purification steps, which requires large volumes of expensive and toxic reagents, as well as solvents. ${ }^{[2]}$ This is the reason why, in the small-scale pharmaceutical industry, the amount of waste per product obtained is huge compared to that of bulk chemicals, ${ }^{[3]}$ which has a longer development time and optimization of the processes (see Fig. 1). The amount of byproducts that are generated during these steps sum up to 20 100 times more volume than the target pharmaceutically active molecule. ${ }^{[4]}$

Therefore, it is necessary to continuously search for reduced number of transformation and purification steps during the synthesis of high quality but affordable therapeutic molecules. A straightforward strategy to improve the sustainability of complex chemical synthesis of pharmaceuticals is to consider how nature
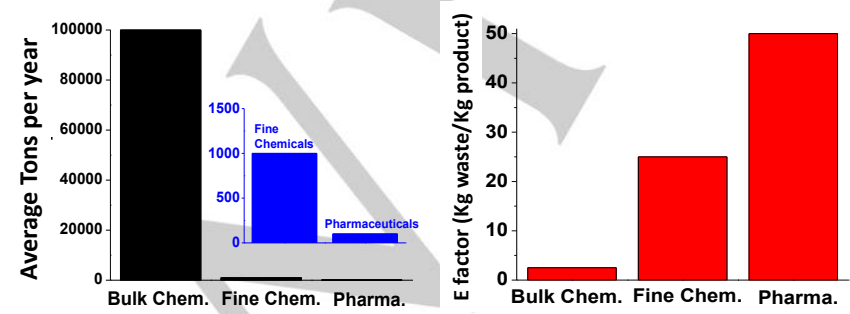

Figure 1. Average product tonnage per year (left part) and E factor (right part) in the synthesis of bulk chemicals, fine chemicals and pharmaceuticals. ${ }^{[4]}$

[a] Dr. Francisco G. Cirujano, francisco.garcia@kuleuven.be Centre for Surface Chemistry and Catalysis, KU Leuven Celestijnenlaan 200F, 3001 Leuven (Belgium) produces biologically active compounds using microscopic machines, known as enzymes. Those natural catalysts are responsible for the clean and efficient synthesis of many bioactive molecules produced naturally by plants or animals through highly active and selective transformations. ${ }^{[5]}$ Unfortunately, enzymes that catalyze C-C and C-N bond forming reactions employed in the synthesis of active pharmaceutical ingredients (such as Knoevenagel condensation, Henry reaction, Michael addition, Friedel-Crafts alkylation, carbene insertion or hydro/oxidative amination reactions) as their natural activity are extremely rare. Currently, it is possible to address enzyme promiscuity directing the evolution of enzymes (within a few months in a lab) into high performance biocatalysts for C-C/C-N bond formation steps invented by chemists, and not by nature (a topic awarded with the 2018 Nobel Prize in Chemistry). ${ }^{[6]}$ However, in most cases it is very expensive to isolate and purify such enzymes (and its necessary cofactors) from biological samples, and the chemical and thermal stability is often limited under very specific operation parameters. Thus, it is desirable to have more robust and cost-efficient catalytic systems that withstand a broader range of reaction conditions and substrate scope, during a longer reaction time, in order to decrease the production costs of the active pharmaceutical ingredients (APIs). Various catalysts, i.e. transition metals and organic molecules, often present compositions and structures similar to those found in natural enzymes, which allows their application as efficient "artificial enzymes" in relevant organic transformations under broader operation parameters. ${ }^{[7]}$ However, such homogeneous catalysts often suffer from deactivation, moderate selectivity and complicated product purification, which limits the translation of the latest breakthroughs from homogeneous catalysis research, to the industrial pharmaceutical production..$^{[8]}$ Industrially, heterogeneous catalysts are desired, since they allow the simple purification and isolation of the active pharmaceutical ingredient from the catalyst by filtration or centrifugation. Moreover, in the targeted hypothesis of negligible leaching, it should be possible the reuse of the solid catalyst, which decrease the production costs. ${ }^{[9]}$ Furthermore, the convenient use of an heterogenized catalyst allows to work with a stable continuous flow of reactants that offers direct separation, step-economy, high reproducibility and easy scale-up. ${ }^{[10]}$

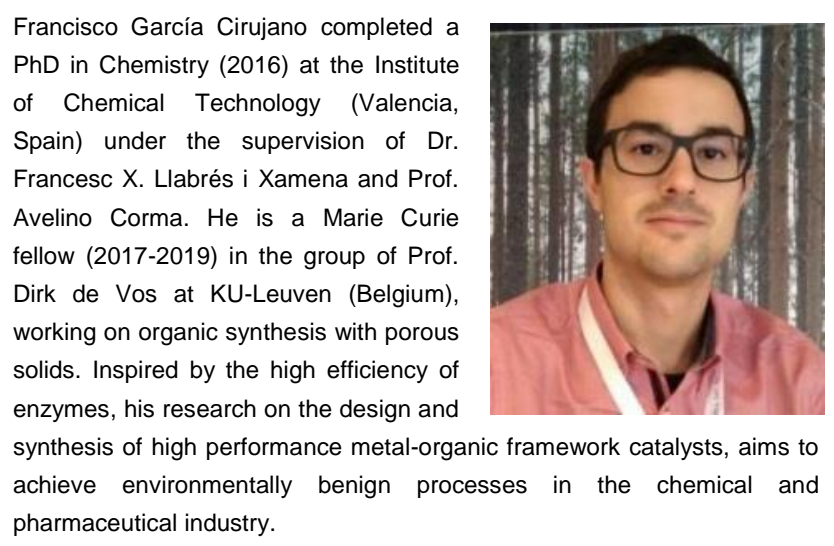


During the last decades, homogeneous catalysts have been extended to robust supramolecular polymeric hybrid materials, such as Metal-Organic Frameworks (MOFs) ${ }^{[11]}$ exhibiting metalorganic functionalities similar to those found in natural enzymes. ${ }^{[12]}$ The full control of the atomic design of the geometry and functionality of such MOF networks have shown potential in stabilizing catalytic centers by isolating the sites (see $\mathrm{Pd}(\mathrm{II})$, $\mathrm{Cu}(\mathrm{II}), \mathrm{Ni}(\mathrm{II})$ sites in Fig. 2 a, b), avoiding their self-deactivation and minimizing its leaching. In a similar manner, the peptide architecture of enzymes separates incompatible active sites in different folded pockets for substrate activation (see Fig. 2 c, d).
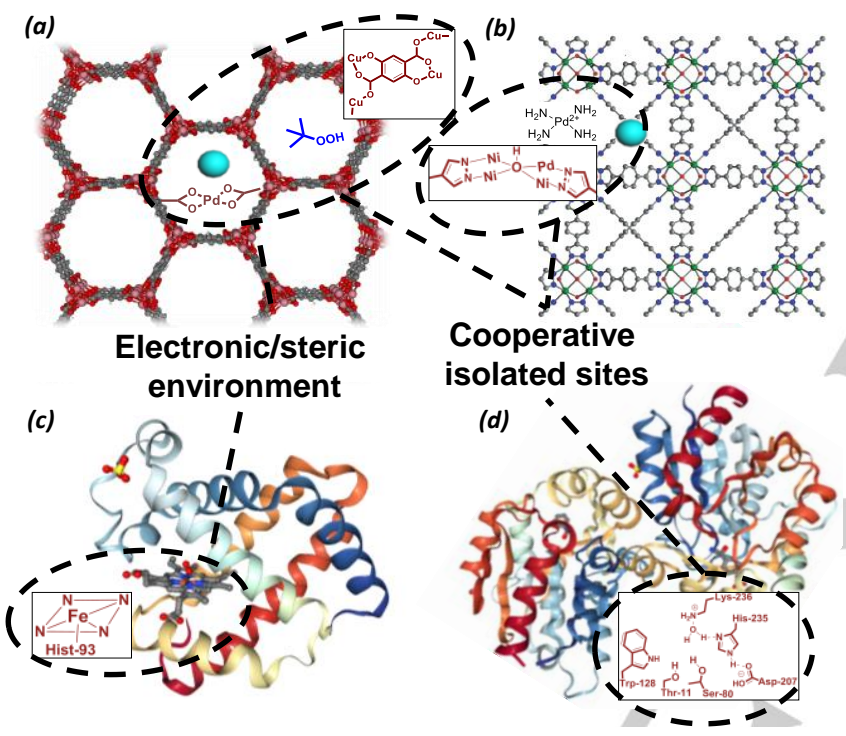

Figure 2. Pd@Cu-MOF-74 (a), Pd@NiBDP (b), Oxymyoglobin (c) and Hydroxynitrile Lyase (d), together with their respective active sites (red inserts). Protein structures (c) and (d) were obtained from the RCSB Protein Data Bank.

Despite the different building blocks (chemical composition) of metal-organic or polypeptide frameworks, in both MOFs and enzymes, it is possible to modify the electronic and steric properties of the catalytic active sites, either by ligand or peptide design, respectively. This will induce selectivity during C-C or C$\mathrm{N}$ bond formation steps by creating an appropriate environment around the active site (insert in Fig. 2) in the restricted space of the porous metal-organic (MOF) or folded polypeptide (enzyme) supramolecular networks. Researchers are also inspired by enzymes when they design MOFs as nanoreactors that separate incompatible active sites in different locations of the framework (metal cluster, organic linker or porous cavity), able to operate cooperatively or in a cascade mode. ${ }^{[13]}$ For instance, acid-base (either Brønsted and/or Lewis) dual functionalities present either at ligands and/or metal sites of the MOF, may lead to multiple types of interactions and synergism during the activation of relatively unreactive substrates, stabilizing intermediates and transition states.

This mini review addresses recent examples of isolated catalytic active sites for the synthesis of APIs. The catalytic performance of well-design MOFs will be compared with that of bioengineered/promiscuous enzymes for a number of versatile and environmentally benign $\mathrm{C}-\mathrm{C}$ and $\mathrm{C}-\mathrm{N}$ bond formation type reactions (see Table 1), together with examples of the pharmaceuticals produced. The discussion is divided in two parts: the first part is focused on various $\mathrm{C}-\mathrm{C}$ bond formation methods, such as enol type additions, alkylations, carbene transfer and oxidative couplings, while the second part describes $\mathrm{C}-\mathrm{N}$ bond formations through hydro-, oxidative- or even epoxide ring-opening amination of alkynes, alkenes and alkanes using amines and azides.

Table 1. MOF or enzyme catalysed $\mathrm{C}-\mathrm{C}$ and $\mathrm{C}-\mathrm{N}$ bond forming reactions to produce pharmaceutically interesting molecules.

\begin{tabular}{|c|c|c|c|c|}
\hline Year ${ }^{[a]}$ & Reaction & Enzyme & MOF & Pharmaceutical \\
\hline \multicolumn{5}{|c|}{$C-C$ bond formations } \\
\hline $\begin{array}{l}1898 \\
2009\end{array}$ & Knoevenagel & $\begin{array}{l}\text { Retro- } \\
\text { aldolase }\end{array}$ & IRMOF3 & $\begin{array}{c}\text { Chromenes and } \\
\text { Pyrimidines }\end{array}$ \\
\hline $\begin{array}{l}1895 \\
2006\end{array}$ & Henry & $\begin{array}{l}\text { Hydroxy- } \\
\text { nitrile lyase }\end{array}$ & Cu@NiBDP & $\begin{array}{l}\text { Norephinephrine } \\
\text { and Rolipram }\end{array}$ \\
\hline $\begin{array}{l}1887 \\
2012\end{array}$ & Michael & Lipase & CDMIL-4 & $\begin{array}{l}\text { Phenibut and } \\
\text { Warfarin }\end{array}$ \\
\hline $\begin{array}{l}1879 \\
2018\end{array}$ & Friedel-Crafts & $\begin{array}{l}\text { Tryptophan } \\
\text { synthase }\end{array}$ & Zr-UiO-66 & $\begin{array}{l}\text { Melatonin and } \\
\text { Sumatriptan }\end{array}$ \\
\hline
\end{tabular}

\begin{tabular}{ccccl}
1954 & $\begin{array}{c}\text { Hydro- } \\
\text { amination }\end{array}$ & B-lyase & Pd@NiBDP & $\begin{array}{l}\text { Antibiotics and } \\
\text { antiretrovirals }\end{array}$ \\
1978 & $\begin{array}{c}\text { Oxidative } \\
\text { amination }\end{array}$ & Citochrome & Fe-UiO & $\begin{array}{l}\text { Pyrrolidine and } \\
\text { sulfonamides }\end{array}$ \\
\hline
\end{tabular}
[a] Year of the first reported reaction using classic organic chemistry (above)
and MOFs or enzymes as catalysts for these processes (bellow).

\section{Mimicking Enzymes with MOFs}

Multiple examples of well-defined metal-ligand coordination bonds responsible for metal-organic supramolecular structures are common in molecular biology, e.g. electrostatic type bonding between a cationic metal and negative charged portions of amino acids in the polypeptide backbone. For example, zinc is present in certain enzymes and in thousands of proteins bonded to DNA, where the zinc ion forms coordination bonds with $\mathrm{N}$, O and $S$ containing ligands from histidine (His), glutamate (Glu), aspartate (Asp) and cysteine (Cys). ${ }^{[14]}$ The different coordination environments generated by the organic ligands have an influence on the chemical properties of zinc ions, being metabolically active or inert.

A structural analogy can be established between biological polymers and coordination polymers. In proteins or nucleic acids, the primary structure is generated by peptide or phosphodiester 


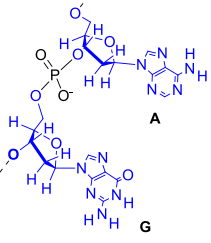

(a)

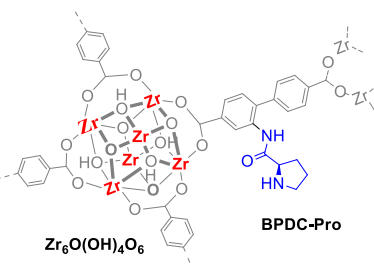

(d)

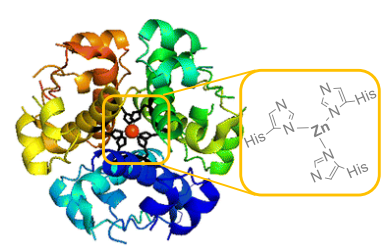

(c)

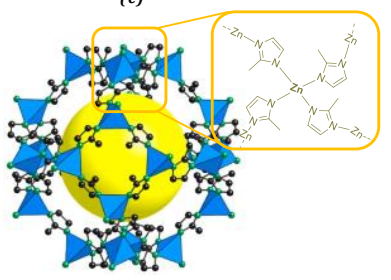

(e)
Figure 3. (a) A-G dinucleotide formed by phosphate diesters of deoxyribose (b) His-Asp-Ser peptide formed by amide bonds and coordination bonds to divalent metals (c) insulin protein macromolecule, reproduced with permission from reference [17], (d) $\mathrm{Zr}_{6} \mathrm{O}$ coordinated to a proline functionalized linker and (e) Zinc-Imidazolate Framework (ZIF-8)

bonds, forming polypeptides or polynucleotides (see Fig. 3 a-c). In MOFs, the framework is formed by coordination bonds between the organic linker and the metal ion (see Fig. $3 \mathrm{~d}-\mathrm{e}$ ). ${ }^{[15]}$ For example, a coordination polymer containing zirconium oxo clusters, $\mathrm{Zr}_{6} \mathrm{O}$, and L-proline functionalized biphenyl-4,4'dicarboxilate linkers as isolated sites (Fig. 3d), ${ }^{[16]}$ presents certain similarities when compared with biological polymers containing isolated nitrogenous bases at the sugar phosphates (Fig. 3a) or amino acids at the polypeptide network (Fig. 3b). Part (a) shows a dinucleotide formed by two purine bases, Adenine $(A)$-Guanine $(G)$, bonded to an inorganic phosphate by a phosphodiester bond. Part (b) shows a peptide with a polyamide backbone containing Histidine (His), Aspartate (Asp) and Serine (Ser) amino acids. Beside the covalent amide bond of the polypeptide chain, the imidazolate (His) and carboxylate (Asp) residues are coordinated to $\mathrm{Zn}^{2+}$ and $\mathrm{Mg}^{2+}$ ions in a similar way to metals and linkers are coordinated in MOFs.

Furthermore, in proteins like insulin, the polypeptide chains are assembled in the form of three pairs of dimers interacting with zinc ions in tetrahedral coordination (Fig. 3c). A similar zinc coordination environment is observed in the $\mathrm{Zn}$ imidazolate zeolite-like framework known as ZIF-8, where four 2methylimidazolate linkers are bonded to a tetrahedral $\mathrm{Zn}^{2+}$ ion (Fig. 3e). Thus, the protein and the MOF have different composition and torsional motions but they are able to organize around the metal ion in a relatively similar manner. The flexibility of both natural and synthetic coordination polymers is clear when exposing the insulin biopolymer to different $\mathrm{NaCl}$ concentrations or ZIF-8 synthetic coordination polymer to water or other guest molecules. ZIF-8 presents a flexible porosity that opens its structure in response to its environment. ${ }^{[18 a]}$ Moreover, the interaction of water molecules with this MOF generates catalytically active zinc-imidazolate acid-base sites, as will be described in the next section. ${ }^{[18]}$

\section{MOFs and enzymes as catalysts for C-C bond formations}

\subsection{Knoevenagel condensation catalyzed by mild acid-base sites}

Following the ubiquitous example of zinc in enzymes, ${ }^{[19]}$ it is accepted that its catalytic properties are largely attributed both to the relatively strong Lewis acidity of $\mathrm{Zn}^{2+}$ and basicity of $\mathrm{Zn}^{2+}$ $\mathrm{OH}^{-}$, acting cooperatively as acid-base catalysts. ${ }^{[20]}$ As described in the previous section, the zinc-imidazolate type coordination found in ZIF-8 metal-organic catalyst (see Fig. 3e) is similar to the coordination identified in the insulin hexamer (see Fig. 3c) and in the active sites of aldolases enzymes. ${ }^{[21]}$ Particularly interesting are type $\mathrm{II}$ aldolases, which contain a $\mathrm{Zn}^{2+}$ ion coordinated to three histidine nitrogen atoms in their active site. They promote the activation of the dihydroxyacetone phosphate nucleophile through the formation of a chelate with both the carbonyl and the hydroxyl groups in the donor. After the abstraction of the $\alpha-\mathrm{H}$ from the dihydroxyacetone starting compound, the enediolate generated is able to react with the carbonyl acceptor RCHO (see Fig. 4). ${ }^{[21]}$

This activation occurs by additional direct coordination of $\mathrm{Zn}^{2+}$ to the carbonyl donor, as described in the Knoevenagel condensation of an aldehyde with malononitrile, ${ }^{[22]}$ catalyzed by ZIF-8 zinc coordination polymers. Unsaturated $\mathrm{Zn}^{2+}$ ions located at the external surface of ZIF-8 are consider to be the catalytic sites. $^{[18 \mathrm{~b}-\mathrm{d}]}$ Raman spectroscopy indicates that two negatively charged $\mathrm{N}$ atoms of malononitrile interact with two $\mathrm{Zn}^{2+}$ ions, acting cooperatively by increasing the acidity of the $\alpha-\mathrm{H}$ from the $-\mathrm{CH}_{2}$ - group (see top right insert in Fig. 4). After losing the activated $\alpha-\mathrm{H}$ from malononitrile, the transient carbanion is stabilized by the $\mathrm{Zn}^{2+}$ ions and attacks the activated carbonyl carbon to form a C-C bond, after dehydration and desorption from the $\mathrm{Zn}^{2+}$ ions (to recover the catalytic sites of ZIF-8). In the case of Zn-MOF-74, the phenolate groups at the organic linker present higher basicity than the carboxylic oxygens atoms. Such basic sites deprotonate the activated methylene compound while the adjacent coordinatively unsaturated metal ions interact with the cyano groups of malononitrile (see bottom left insert in Fig. 4).

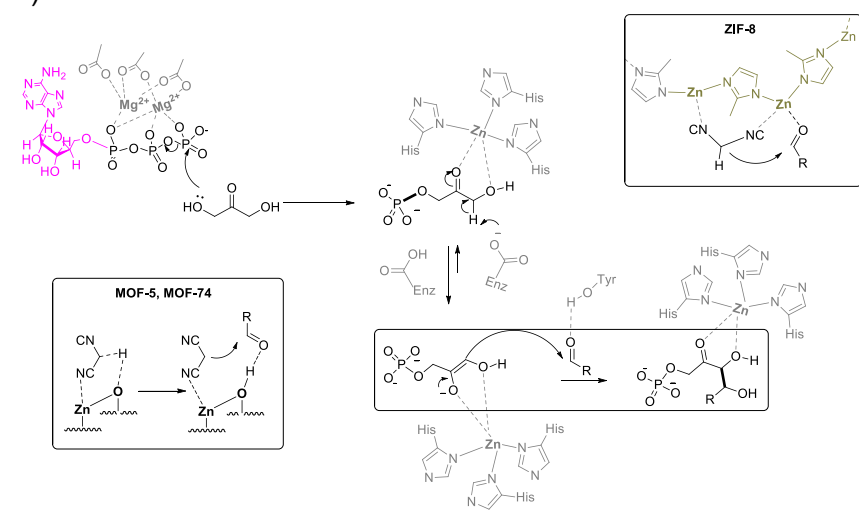

Figure 4. Malononitrile activation in MOF-5, MOF-74 and ZIF-8 versus the biochemical activation of dihydroxyacetone phosphate and reaction with an aldehyde to produce a ketose 1-phosphate, catalyzed by a type II aldolase. 
Therefore, the deprotonation of the activated methylene depends on its adsorption at the coordinatively unsaturated metal sites and the subsequent deprotonation by the adjacent phenolate groups. ${ }^{[23]}$ Zinc carboxylate MOFs with noncoordinated amino groups, such as IRMOF-3, were employed as solid basic catalysts for the Knoevenagel condensation of ethyl cyanoacetate with benzaldehyde. ${ }^{[24]}$ The reaction rate obtained with this material was superior to other MOF catalysts without amino groups and applied in the multicomponent synthesis of 4Aryl-4H-chromenes, employed as apoptosis inducers (compound $\mathbf{1}$ in Fig. 5), ${ }^{[25]}$ and substituted dihydropyrimidines, as calcium channel blockers (compound 2 in Fig. 5). ${ }^{[26]}$
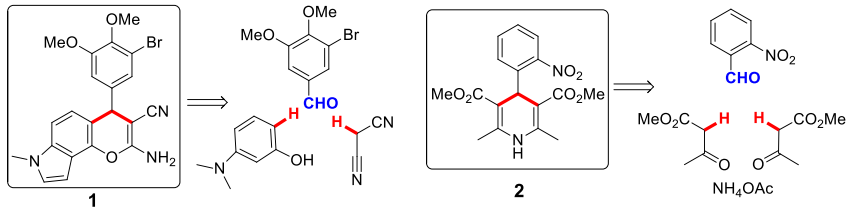

Figure 5. Chromene (1) and pyrimidine (2) anticancer drugs prepared from malononitrile or methyl acetoacetate and substituted benzaldehydes.

In the case of IRMOF-3, the deprotonation of ethyl cyanoacetate is promoted by the cooperative action of the aromatic amino group and the oxygen atom from the zinc carboxylate cluster (see IRMOF-3 route "a" in Fig. 6). ${ }^{[27]}$ The cooperative catalysis between two basic sites (a Lewis oxygen base together with a Brønsted amine base) stabilizing a quasi-planar six-membered ring transition state after the deprotonation of the substrate, is different from Zn-imidazolate-Zn or Zn-phenolate Lewis acidacid or acid-base pairs in ZIF-8 or MOF-74, respectively (see Fig 4). The mechanism of the Knoevenagel condensation when these $-\mathrm{NH}_{2}$ groups participate resembles that of natural cysteine protease enzymes (such as papain) and artificial retro-aldolases (such as RA95.5-8), where no metal sites participate in the activation of the substrates. The active site of the papain globular protein contains an oxyanion hole formed by the $-\mathrm{NH}$ groups of the backbone of Cys-25 and the sidechain of a Gln-19. They cooperatively activate, through hydrogen bonding catalysis the acetylacetone substrate that is eventually deprotonated by a nearby histidine (His-159) residue (see papain in Fig. 6). ${ }^{[28]}$

The IRMOF-3 route "b" in Fig. 6 highlights the formation of an imine intermediate by the covalent bonding of the amino groups, present in the aromatic ring of the MOF linker, with the benzaldehyde substrate. ${ }^{[24]}$ The same mechanistic route has been reported for type I aldolases, such as the optimized RA95.5-8 enzyme. ${ }^{[29]}$ This in vitro evolved biocatalyst promotes the Knoevenagel condensation of highly deactivated aldehydes by forming a Schiff-base intermediate with a nucleophilic lysine in an apolar pocket (see RA95.5-8 in Fig. 6). The imine catalysis was claimed as the most probable mechanism in the case of IRMOF-3 (route $b$ in Fig. 6), resulting in a 3-fold increase in the reaction rate with respect to the blank reaction in DMF. ${ }^{[24]}$ However, the catalytic performance of the RA95.5-8 biocatalysts results in a 30 -fold enhanced activity for the Knoevenagel reaction in water.

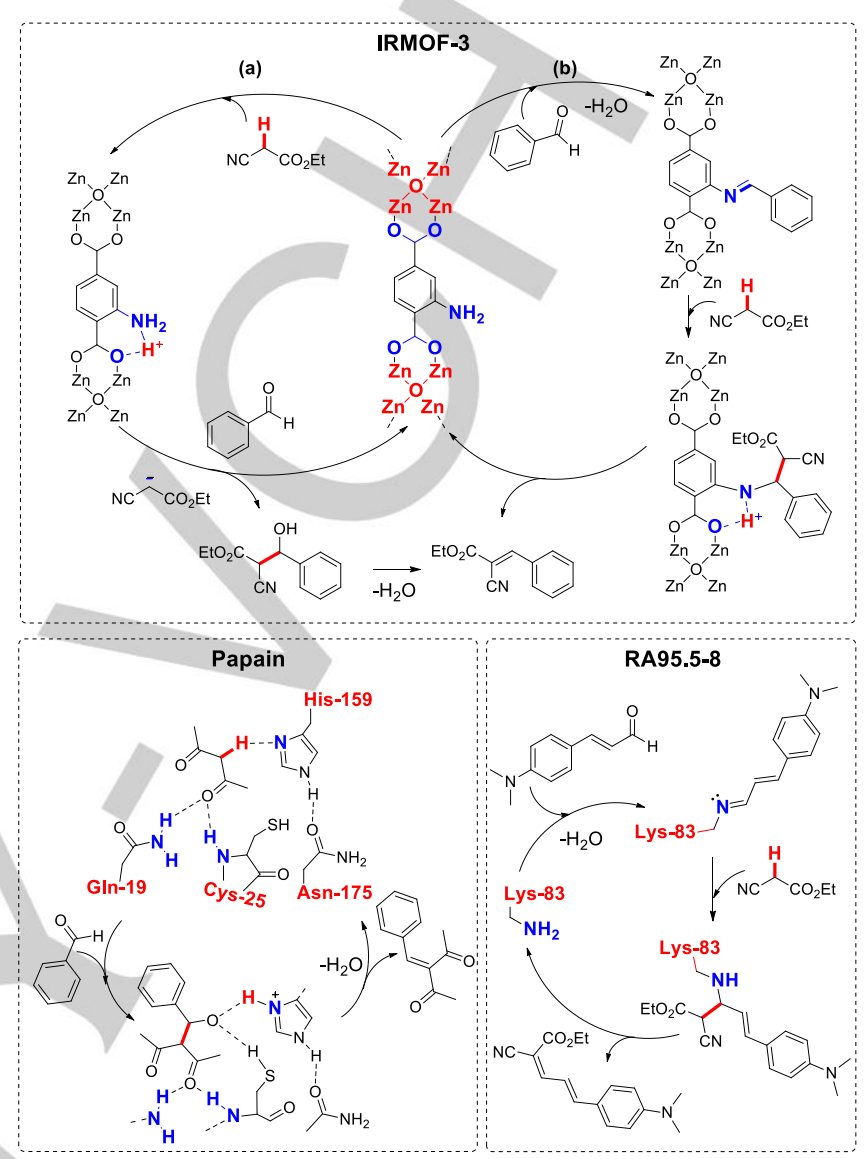

Figure 6. Proposed mechanisms for the Knoevenagel condensation using IRMOF-3 or enzymes (papain and RA95.5-8) -NH containing catalysts.

\subsection{Henry reaction, a nitro aldol condensation leading to bio-active $\mathrm{N}$-containing molecules}

Another example of C-C bond formation is the Henry or nitro aldol condensation between nitro alkanes and carbonyl compounds. ${ }^{[30]}$ It is one of the synthetic steps that leads to important pharmaceuticals, such as norepinephrine (compound 3 in Fig. 7) ${ }^{[31]}$ or Phenibut (compound 4 in Fig. 7), a GABA ( $\gamma^{-}$ amino butyric acid neurotransmitter) receptor agonist applied in the treatment of multiple neurological pathologies. ${ }^{[32]}$
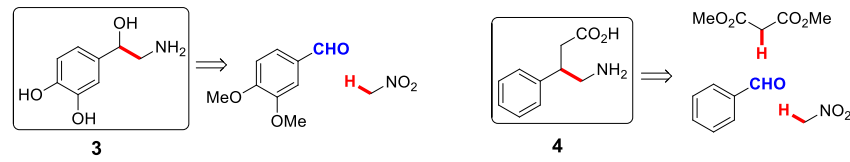

Figure 7. Norephinephrine (3) and Phenibut (4) neuroactive pharmaceuticals, which can be prepared from nitromethane and aromatic aldehydes.

A highly porous-non-interpenetrated framework formed by octahedral nickel oxoclusters connected to benzene bispyrazolate (BDP) linkers has been recently employed as heterogeneous catalyst for the synthesis of nitro alkene pharmaceutical intermediates. ${ }^{[33]}$ The $\mathrm{Cu}^{2+}$ exchanged MOF (NiBDP@Cu) promotes the Henry reaction between benzaldehyde and nitromethane, forming the $\mathrm{C}-\mathrm{C}$ bond in the 
corresponding nitro alcohol that further dehydrates into the nitro alkene product. The proximity of the $\mathrm{Ni} / \mathrm{Cu}-\mathrm{O}$ acid-base sites of the inorganic cluster together with the polar functional group ($\mathrm{NH}_{2},-\mathrm{OH}$ ) of the BDP linker cooperatively interact with the nitro and carbonyl groups of the substrates, favoring the charge delocalization and making carbanions easier to form (see left part of Fig. 8). The positive effect of the organic functional groups on the catalytic activity of the MOF is clear when a polar functional group $\left(-\mathrm{NH}_{2},-\mathrm{OH}\right)$ is present in the linker, since its activity in the Henry reaction is much higher ( $80 \%$ yield) with respect to the use of non-functionalized NiBDP ( $40 \%$ yield). It is worth mentioning that the number of turnovers employing the MOF as catalyst (after 3 re-cycles) is five times higher (and more selective) respect to the use of stoichiometric amounts of nonreusable $\mathrm{NaOH}$

In the case of biocatalyzed aldol condensations, similar type of cooperative interactions (as those reported for the $\mathrm{Cu}-\mathrm{Ni}$ pyrazolate MOF) occurs with $\mathrm{Zn}^{2+}$-Hys active sites in type II aldolases or catalytic triads of amino acids in papain (see section 3.1). The same nitro aldol reaction between nitromethane and benzaldehyde is also biocatalyzed by the metal-free promiscuous hydroxynitrile lyase from Hevea brasiliensis $(\mathrm{HbHNL}){ }^{[34]}$ The amino acid residues at the active site of the enzyme act cooperatively during the stereoselective $\mathrm{C}-\mathrm{C}$ bond formation through a nitro aldol condensation at $\mathrm{pH} 7$ in a biphasic aqueous/organic solvent mixture (see Fig. 8 right). Despite the reduced solubility of nitromethane in the aqueous phase, the corresponding nitro alcohol is formed in high yields $(63 \%)$ and excellent enantiomeric excess (93\% e.e.) after $48 \mathrm{~h}$ (see Table 2). ${ }^{[35 a]}$

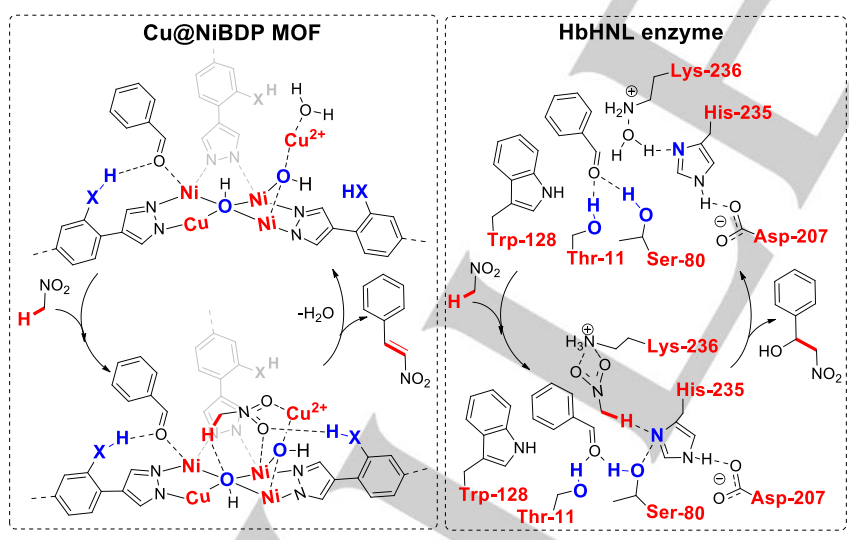

Figure 8. Proposed mechanism for the nitro aldol condensation using the Cu@NiBDP MOF or HbHNL type enzyme as cooperative catalysts.

The right part of Fig. 8 shows how the carbonyl group of benzaldehyde is activated through hydrogen bonds with the side chains of Ser80 and Thr11. Then, the nitro group of nitromethane interacts with the positively charged Lys236, which facilitates its deprotonation by the Ser80/His235/Asp207 catalytic triad. The subsequent dehydration of the nitro alcohol adduct to afford the $\beta$-nitrostyrene product does not occurs at the oxyanion hole of the enzyme and generally requires high temperatures or strong basic conditions, as in the case of Cu@NiBDP (2-butanol reflux, 48 h). However, the formation of the nitro alkene has been reported with the optimized RA95.5-8 amino biocatalyst through the corresponding imine intermediate (see RA95.5-8 in Fig. 6). ${ }^{[36]}$ Manganese dependent hydroxynitrile lyase from Granulicella tundricula (GtHNL) have been also employed as promiscuous enzyme under similar reaction conditions to metal-free $\mathrm{HbHNL}$, but obtaining $75 \%$ conversion of benzaldehyde after $24 \mathrm{~h}$, with $94 \%$ e.e. of the $(R)$-nitro alcohol enantiomer. ${ }^{[35 b]}$ Both the protein and manganese ion bound to the GtHNL are necessary for the nitro aldol activity. When this ion is exchanged with $\mathrm{Fe}$ or $\mathrm{Co}$ ions, the enzymes were more active than those with $\mathrm{Mn}$ (see Table 2).

Novel organocatalytic approaches using MOFs incorporating the urea scaffold (UiO-67 $7_{\text {urea }}$ ) have also been attempted with the aim of designing enzyme-like hydrogen-bond donating catalysts. During the $1^{\text {st }}$ reaction cycle, the nitro alcohol product is obtained in $67 \%$ yield after just $24 \mathrm{~h}$ at room temperature (see Table 2). ${ }^{[37 a]}$ Recent post-synthetic modification of chiral MOFs by hydrogenating the "salen" ligand (into "salan"), provides a more flexible chiral group and more alkaline backbone, which resulted in significantly enhanced activity for the asymmetric Henry reaction with excellent enantioselectivity (see Table 2). ${ }^{[37 b]}$

Table 2. Nitro aldol condensation of benzaldehyde with nitromethane.

\begin{tabular}{|c|c|c|c|c|}
\hline Catalyst & Reaction conditions & Yield (\%) ${ }^{[a]}$ & e.e. (\%) & Ref \\
\hline $\mathrm{NaOH}$ & $\begin{array}{c}10-30 \stackrel{\circ}{\circ} \mathrm{C}, 0.5 \mathrm{~h}, \\
\text { water }\end{array}$ & 85 & - & [b] \\
\hline Cu@NiBDP & $\begin{array}{c}110^{\circ} \mathrm{C}, 48 \mathrm{~h}, 2- \\
\text { butanol }\end{array}$ & $80(63)^{[c]}$ & - & [33] \\
\hline $\mathrm{HbHNL}$ & $\begin{array}{c}\mathrm{RT}, 48 \mathrm{~h} \text {, water- } \\
\mathrm{TBME}^{[\mathrm{d}]}\end{array}$ & 63 & 93 & [35a] \\
\hline GtHNL(Mn) & $\begin{array}{l}\mathrm{RT}, 4 \mathrm{~h} \text {, water- } \\
\mathrm{TBME}^{[\mathrm{d}]}\end{array}$ & 29 & 95 & [35b] \\
\hline GtHNL(Co) & $\begin{array}{c}\mathrm{RT}, 4 \mathrm{~h} \text {, water- } \\
\text { TBME[d] }^{[\mathrm{d}]}\end{array}$ & 45 & 97 & [35b] \\
\hline UiO-67 urea & $\begin{array}{l}\mathrm{RT}, \text { 24h, THF, } \\
\quad \mathrm{ir}_{2} \mathrm{EtN}\end{array}$ & 67 & - & {$[37 a]$} \\
\hline $\begin{array}{l}\mathrm{Cd}_{2}(\mathrm{Cu}(\mathrm{sal})) \\
(\mathrm{DMF})_{3}\end{array}$ & $\begin{array}{c}45^{\circ} \mathrm{C}, 48 \mathrm{~h}, \\
\text { methanol, DIPEA }\end{array}$ & 71 & 95 & [37b] \\
\hline
\end{tabular}

[a] Yield to the corresponding nitro alcohol product 2-nitro-1-phenylethanol. [b] Vogel's "Practical Organic Chemistry", 5th Ed, 1035-1036.

[c] Yield of $\beta$-nitrostyrene after the $3^{\text {th }}$ reuse of the MOF catalyst.

[d] TBME: tert-butyl methyl ether. [e] DIPEA: $N, N$-diisopropylethylamine.

The enantioselectivity of this $\mathrm{Cd}_{2}(\mathrm{Cu} \text { (salan))(DMF) })_{3}$ MOF is higher than that of the corresponding homogeneous counterpart $\mathrm{Cu}\left(\mathrm{H}_{4}\right.$ salan $)$, demonstrating the beneficial combination of the chiral framework confinement and synergistic effects. Despite from the harsh conditions needed with Cu@NiBDP, this heterogeneous catalyst can be reused in subsequent reaction cycles with only a slight decrease in the final reaction yields 
(from 81 to $63 \%$ after the third reuse) and no leaching of active species after hot-filtration tests. ${ }^{[33]}$ On the contrary, there is little information about stability, regeneration and reuse of enzyme biocatalysts. Enzymes are usually mechanically, thermally and chemically more sensible than the synthetic MOFs described, often requiring to be immobilized in a solid support, e.g. MOFs, that increases the cost of the process. ${ }^{[38]}$ Excellent reviews about the catalytic performance of several enzymes immobilized in MOFs are recently available, ${ }^{[38 c-9]}$ from which one particular example is described in the next section, i.e. Lipase/UiO-66.

\subsection{Michael type conjugate addition of nucleophiles to electron-poor alkenes}

The most common example of base-catalyzed Michael addition employs $\alpha, \beta$-unsaturated compounds, such as the nitro olefins generated from the Henry reaction. ${ }^{[39]}$ An alternative to the soluble base used as catalyst, which requires additional work-up steps, ${ }^{[40]}$ is the use of metal-organic frameworks as heterogeneous catalysts. ${ }^{[41]}$ Michael addition steps allow to obtain Rolipram (compound $\mathbf{5}$ in Fig. 9), a selective phosphodiesterase-4 inhibitor, ${ }^{[42]}$ or Warfarin (compound 6 in Fig 9 ), a vitamin $K$ antagonist and one of the most effective anticoagulants. ${ }^{[43]}$

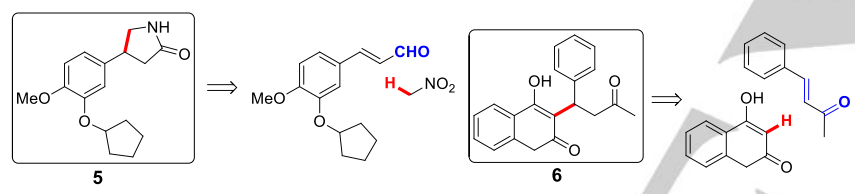

Figure 9. Rolipram (5) and Warfarin (6) neuroactive and anticoagulant, respectively, pharmaceuticals obtained through Michael additions.

Promiscuous lipase enzymes have been employed as catalysts for the Michael addition of 4-hydroxycoumarin to benzylideneacetone, producing $(R)$-Warfarin in $85 \%$ yield and $46 \%$ e.e. after 7 days of reaction in anhydrous DMSO at room temperature (see Table 3). ${ }^{[44]}$ The $\alpha, \beta$-unsaturated benzylideneacetone binds to the oxyanion hole of the enzyme, where Gln-106 and Thr-40 stabilize the formation of an enolate by three hydrogen bonds with the carbonyl oxygen of the $\alpha, \beta$ unsaturated compound (see Fig. 10 left). ${ }^{[4]}$ His-224 acts as a general base to activate the carbon nucleophile of 4hydroxycoumarin by removing one of its $\alpha-H$. The two substrates are then close to each other in the active site, which results in a nucleophilic attack of the carbon nucleophile to the $\alpha, \beta$ unsaturated carbonyl compound.

To overcome the drawbacks of enzyme biocatalysts, such as poor long-term stability as well as the difficulties in recovering and recycling, a lipase enzyme was immobilized on UiO-66(Zr) MOF. ${ }^{[46]}$ The well-dispersed enzyme in the MOF support was reported to be more active than the pure enzyme in solution, when employed as catalyst for the synthesis of Warfarin in methanol at $50 \stackrel{\circ}{\circ}$ ( 61 vs. $87 \%$ yield). Moreover, in contrast to the pure enzyme in solution, it is possible to reuse the lipase/UiO-66 bio-reactor in at least five cycles with minor loss in catalytic activity $(71 \%$ yield $)$.

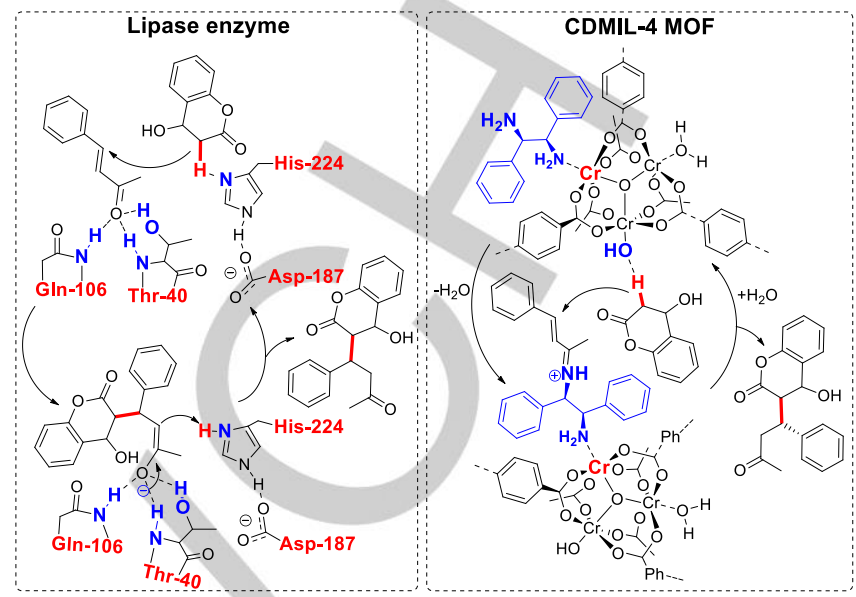

Figure 10. Michael addition catalyzed by lipase enzyme (left) or CDMIL-4 MOF (right) in the synthesis of Warfarin.

Other MOFs containing coordinatively unsaturated sites and high porosity, such as the MIL-101(Cr) MOF, were also employed as mesoporous supports of the chiral primary diamine organocatalyst $(1 R, 2 R)$-1,2-diphenylethylenediamine (see Fig. 10 right). ${ }^{[4]}$ The loaded MOF (named as CDMIL-4) catalyze the asymmetric Michael addition of 4-hydroxycoumarin to benzylidene acetone in THF at room temperature, producing $(R)$-Warfarin in $78 \%$ yield and $69 \%$ e.e. The amount of grafted $(1 R, 2 R)-1,2$-diphenylethylenediamine and thus, the yield and e.e. of the Warfarin product slightly decrease upon reuses (see Table 3).

Table 3. Michael addition of 4-hydroxycoumarin to benzylideneacetone.

\begin{tabular}{ccccc}
\hline Catalyst & Reaction conditions & Yield (\%) & e.e. (\%) & Ref \\
\hline $\mathrm{Et}_{3} \mathrm{~N}$ & Reflux, $48 \mathrm{~h}$, water & 80 & - & {$[43]$} \\
Lipase & $\mathrm{RT}, 7$ days, DMSO & 85 & 46 & {$[44]$} \\
$\begin{array}{l}\text { Lipase/ } \\
\text { UiO-66 }\end{array}$ & $50^{\circ} \mathrm{C}, 24 \mathrm{~h}$, methanol & $87(71)^{[\mathrm{a}]}$ & - & {$[46]$} \\
CDMIL-4 & $10 \stackrel{\circ}{\circ} \mathrm{C}, 24 \mathrm{~h}, \mathrm{THF}$ & $94(60)^{[\mathrm{b}]}$ & $83(79)$ & {$[47]$} \\
\hline
\end{tabular}

[a] $5^{\text {th }}$ reuse. ${ }^{[b]} 3^{\text {th }}$ reuse.

\subsection{Alkylation and alkenylation of activated arenes: C-H functionalization of electron-rich indoles}

Electron deficient alkenes, such as the $\beta$-nitrostyrene formed during the Henry reaction step (section 3.2), were employed for the Friedel-Crafts alkylation of indole. ${ }^{[48]}$ The pharmaceutically interesting substituted indoles obtained resemble those present in commercial drugs, such as Melatonin (compound 7 in Fig. 11) $)^{[49]}$ or Sumatriptan (compound 8 in Fig. 11). ${ }^{[50]}$ The NiBDP@Cu MOF described previously, shows a much better performance (turnovers twice as high) than state-of-the-art Ni/Cu 


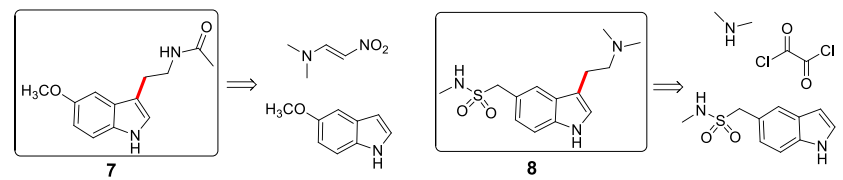

Figure 11. Melatonin (7) and Sumatriptan (8) neuroactive pharmaceuticals that may be formed through Friedel-Crafts alkylation and acylation steps.

catalysts in the Friedel-Crafts alkylation of indole with $\beta$ nitrostyrene. ${ }^{[33]}$ However, the use of Zn-MOF-5 as precursor of well-dispersed $\mathrm{ZnO}$ in aluminosilicates, generates MOF derived metal oxides with turnovers two orders of magnitude higher than the parent MOF. ${ }^{[51]}$ Moreover, homochiral Cu-MOFs constructed from $(R)$-2,2'-dihydroxy-1,1'-binaphthyl-6,6'-dicarboxylic acid and $\mathrm{Cu}\left(\mathrm{NO}_{3}\right)_{2}$ have been reported for the same reaction, obtaining high yields of the alkylated indole (82\%) with excellent enantioselectivities ( $90 \%$ e.e.). ${ }^{[52]}$

A green approach to carry out the $\mathrm{C}-\mathrm{H}$ functionalization of the indole heteroarene is to employ alcohols as alkylating agents, generating only water as waste. The oxophilic Zr-UiO-66 metalorganic framework show high activity for this (Brønsted) acid catalyzed dehydrative coupling of alcohols and indole. ${ }^{[53]}$ Thus, a proton transfer from the $-\mathrm{O}-\mathrm{Zr}-\mathrm{OH}_{2}$ - inorganic cluster to the alkylating alcohol generates a transient carbocation that reacts with the electron rich C3 of indole to selectively form the C-C bond in the functionalized indole product (see Fig. 12, left). The restricted pore size of the microporous MOF avoids the subsequent $\mathrm{C} 2$ alkylation of the $\mathrm{C} 3$ substituted indole, in contrast to ionic liquid catalysts. The biological equivalent of this reaction is performed by the engineered tryptophan synthase, in a pyridoxal phosphate-dependent reaction giving tryptophan as product (see Fig. 12, right). ${ }^{[54]}$

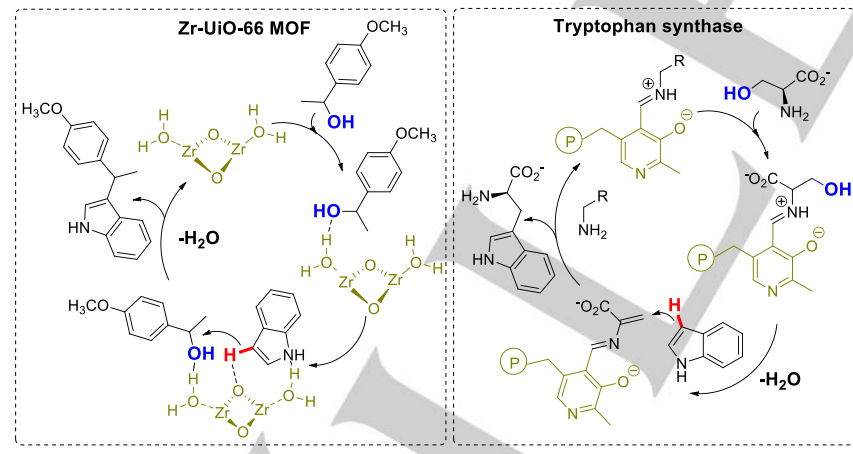

Figure 12. $\mathrm{C}-\mathrm{H}$ functionalization of indole with alcohols as alkylating agents, catalyzed by Zr-UiO-66 MOF (left) or tryptophan synthase enzyme (right).

A different $\mathrm{C}-\mathrm{C}$ bond forming methodology is the $\mathrm{Pd}$ catalyzed oxidative olefination of electron-rich arenes with electron-poor olefins in the presence of oxidants, such as $t$ butyl hydroperoxide (TBHP) ${ }^{[55]}$ As occurs with the alkylation with alcohols, the olefination takes place at the electron-rich C-3 position of indole through an electrophilic palladation during the $\mathrm{C}-\mathrm{H}$ cleavage. By using redox active MOFs, which also favor the concentration of TBHP inside their porous architecture, it is possible to increase the lifetime of the confined palladium active sites. The oxidative microenvironment of the TBHP/Cu-MOF-74 system favors that the $\mathrm{Pd}^{0}$ (generated during the catalytic cycle) is oxidized back to $\mathrm{Pd}^{2+}$, under room temperature and ambient pressure (see Fig. 13 left). This allows for the $\mathrm{C} 3-\mathrm{H}$ bond functionalization of indoles into $\mathrm{CysLT}_{1}$ selective antagonists and $\mathrm{C} 5-\mathrm{H}$ bond functionalization of uracils into potential antiviral or anti cell proliferation drugs. ${ }^{[56]}$ The number of $\mathrm{Pd}$ turnovers increase from just 3 , for the homogeneous $\mathrm{Pd}(\mathrm{OAc})_{2}$, to 13 when they are isolated in the appropriate environment created by the MOF, under the same reaction conditions.

Other alkylation reagents employed for the $\mathrm{C}-\mathrm{H}$ functionalization of indole are diazo compounds, such as diazoacetic esters, as carbene precursors. On the one hand, Pd-MOF nanoreactors show good performance for similar type of carbene bonding chemistry. ${ }^{[57 a]}$ On the other hand, cytochrome P450 mutant enzyme with more electrondonating axial ligands (on the polypeptide backbone) modifies the redox potential/electronic environment of the biocatalyst active site (favoring the reduced $\mathrm{Fe}^{2+}$ active site) which results in turnover numbers up to 7100 , with enhanced enantioselectivities for cyclopropanation reactions. ${ }^{[57 b]}$ After this seminal work, other groups have also engineered variants of myoglobin (Mb). ${ }^{[58]}$ This provide efficient biocatalysts for the transformation of a broad range of indoles in the presence of ethyl $\alpha$-diazoacetate to give the corresponding C3-functionalized derivatives in high yields and excellent chemoselectivity at room temperature (TONs of 106 vs. 1 for the non-optimized myoglobin). The ferrous Mb-catalyzed carbene transfer reactions are believed to proceed via the formation of an electrophilic heme-bound carbene intermediate, which may react with the indole nucleophile at the C3 site (see Fig. 13 right).

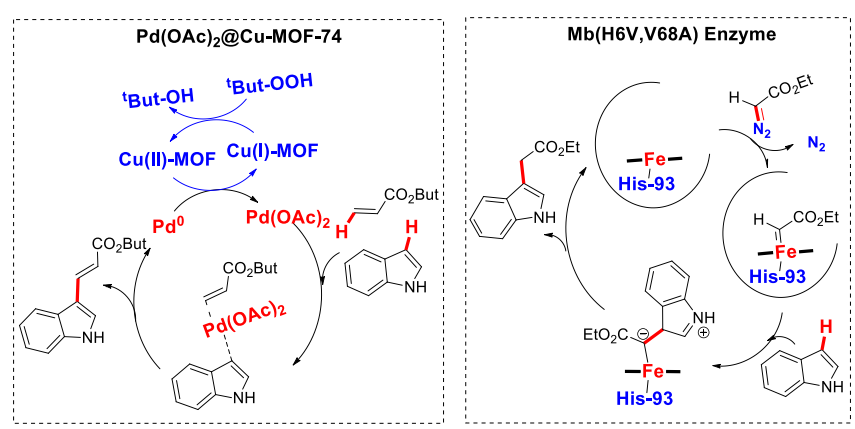

Figure 13. $\mathrm{C}-\mathrm{H}$ activation of indole using $\mathrm{Pd}(\mathrm{OAc})_{2}$ in MOFs and olefins (left), or an optimized myoglobin enzyme and diazo compounds (right).

Chiral groups fixed in MOFs have been employed to create a new stereogenic center at the substituted indole, producing preferentially one enantiomer during the alkylation reaction. Indeed, MOFs provides an attractive platform for designing privileged single-site chiral catalysts installed into organic linkers, controlling its environment, reactivity and stereoselectivity in $\mathrm{C}-\mathrm{C}$ bond formations. Wembin Lin and co-workers developed chiral MOFs built from enantiopure BINOL phosphoric acid-derived ligands and $\mathrm{Cu}_{2}$ (carboxylate) ${ }_{4} \mathrm{SBU}$, containing both a chiral cavity for enzyme-like stereocontrol and large open channels for substrate and product transport. The chiral environment of 
the MOF cavity, resembling the stereocontrol of the enzyme pocket in enzymatic catalysis, catalyzed asymmetric Friedel-Crafts reactions between indoles and imines. ${ }^{[59 a]}$ More recently, Yong Cui and co-workers employed chiral phosphono-carboxylate groups of 1,1'-biphenol that, together with the metal ions and phenyl rings, create an appropriate microenvironment in the restricted space of the MOF, which concentrate the reactants and generates additional steric and electronic effects around the $\mathrm{Mn}^{2+}$ active sites. ${ }^{[59 b]}$ The chiral and reusable (up to 10 times) Mn-MOF allows to carry out the synthesis of the optically enriched indolobutyric acid, a cyclooxygenase-2 (COX-2) inhibitor, in $72 \%$ yield and with $95 \%$ e.e., through a FriedelCrafts alkylation of an indole derivative followed by hydrolysis and oxidation steps.

\section{MOFs and enzymes as catalysts for $\mathrm{C}-\mathrm{N}$ bond formations}

\subsection{Hydroamination of alkenes and alkynes using amines}

Formation of C-N bonds is probably the most important process in organic chemistry after $\mathrm{C}-\mathrm{C}$ bond formation. The direct addition of amines to unsaturated $\mathrm{C}-\mathrm{C}$ bonds, in the presence of a suitable catalyst, is a superior route respect to other alkylating agents (e.g. carbonyls) in terms of more economic raw materials and better atom efficiency. One of the first attempts to react an amine nucleophile with an olefin to make synthetically useful alkyl amines was reported in the fifties of last century, using very harsh conditions (metallic sodium at $200{ }^{\circ} \mathrm{C}$ and 1000 atm). ${ }^{[60]}$ During the following decades, novel organometallic homogeneous catalysts based also on alkaline earth metals were employed under milder conditions typical of enzymes, allowing for intramolecular hydroaminations at room temperature in just $15 \mathrm{~min}$ and using $10 \mathrm{~mol} \%$ of a $\mathrm{Ca}$ based homogeneous catalyst. ${ }^{[61]}$

In order to immobilize alkaline earth metal active sites, the metalation of a $\mathrm{Zr}$ MOF with $\mathrm{Me}_{2} \mathrm{Mg}$ resulted in an heterogeneous catalyst for the same hydroamination of aminopentenes. ${ }^{[62 a]}$ However, its activity was lower than the homogeneous $\mathrm{Ca}$ catalyst, and only after 2 days of stirring the $1 \mathrm{~mol} \% \mathrm{Mg}$ containing MOF with the aminopentene reagent in benzene at $80 \stackrel{\circ}{\circ}$, the corresponding pyrrolidine was formed in quantitative yields $(>90 \%)$. The same group reported the design of BINAP-Zr-MOFs with a similar UiO topology and their post-synthetic metalation with $\mathrm{Rh}$ complexes, to afford highly active and enantioselective single-site solid catalysts for asymmetric cyclization reactions, yielding substituted pyrrolidines. ${ }^{[62 \mathrm{~b}]}$ The comparable e.e. and higher catalytic activity respect to the homogeneous controls, is likely a result of catalytic site isolation in the MOF, which prevents bimolecular catalyst deactivation pathways. The five member ring azaheterocycles obtained are interesting compounds as dual neurokinin receptor antagonists and selective serotonin reuptake inhibitors, which allow their use in the treatment of pain, inflammation or schizophrenia, ${ }^{[63]}$ and even as glucokinase activator for the treatment of type II diabetes. ${ }^{[64]}$ Since the sixties of last century, it is known that stoichiometric amounts of $\mathrm{PdCl}_{2}$ promotes hydroamination reactions under mild conditions. ${ }^{[65]}$ In order to decrease toxicity and cost of $\mathrm{Pd}$ homogeneous catalysts, $\mathrm{Pd}$ and $\mathrm{Pt}$ pincer complexes were recently used for the assembly of porous $\mathrm{Zr}$ MOFs, in an attempt to immobilize the active sites for $\mathrm{C}(\mathrm{sp})-\mathrm{H}$ activation. Using only $5 \mathrm{~mol} \% \mathrm{Pd}$ catalyst, the intramolecular hydroamination of an o-substituted alkynyl aniline produces the same amount of substituted indole as with homogeneous catalysts (TONs around 20) in dioxane at $90{ }^{\circ} \mathrm{C}$ for $12 \mathrm{~h}$, for a single reaction cycle. ${ }^{[6]}$ The substituted indoles obtained as hydroamination product are interesting scaffolds present in serotonine reuptake inhibitors (see compounds 7 and 8 in section 3.4). In a parallel study, well-dispersed $\left[\mathrm{Pd}\left(\mathrm{NH}_{3}\right)_{4}\right]^{2+}$ sites have been introduced in the defective K@NiBDP nickel pyrazolate framework described in previous sections. ${ }^{[67]}$ The resulting porous crystalline material has an adequate site isolation and framework environment to promote both intra- and intermolecular hydroamination of terminal alkynes with excellent activity, reusability and selectivity towards the corresponding indole or imine against the hydration of the alkyne (selectivity to the imine $\sim 70 \%$ and TON $\sim 40$ after the second use). The $\mathrm{Pd}^{+2}$ catalyzed hydroamination may proceed through the coordination of palladium sites to the alkyne and amine groups of the substrates, which facilitates the addition of the amine to the alkyne (see Fig. 14 left).

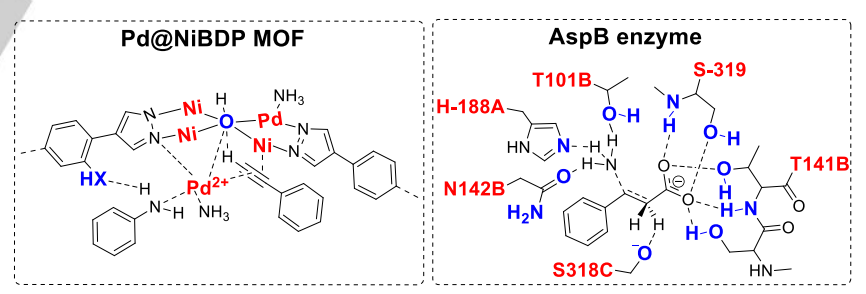

Figure 14. Hydroamination of alkynes and alkenes catalyzed by Pd@NiBDP MOF (left) or AspB $\beta$-lyase enzyme (right), respectively.

In contrast to traditional organometallic chemistry, nowadays biotechnology is able to tailor $\beta$-lyase enzymes (with metal-free active site) in order to interact with the C-C unsaturated bond of the olefin reagent. In particular, they activate the $\mathrm{C}\left(\mathrm{sp}^{2}\right)-\mathrm{H}$ bond of $(E)$-cinnamic acid through purely organocatalytic interactions at the enzyme folded pocket containing the required cooperative active sites. The enzyme catalyzed process does not require for any metalation of $\mathrm{C}-\mathrm{H}$ bonds, but only multiple hydrogen bond interactions to stabilize the transition state. Those are based on the accommodation of the phenyl group and stabilization of the carboxylate by delocalizing the negative charge in tailored binding pockets (see Fig. 14 right). ${ }^{[68]}$ The addition of ammonia (stabilized through hydrogen bonds with three amino acids) to the $\alpha, \beta$-unsaturated carboxylic acid produces (S)- $\beta$-phenylalanine, which is the chiral precursor of several antibiotics or antiretroviral compounds. 


\subsection{Oxidative/ epoxide ring opening amination type reaction using azides/ amines}

Despite from the widespread use of $\mathrm{Pd}$ during the last decades, ${ }^{[69]}$ earth abundant non-toxic metal catalysts are desired in organic synthesis. For instance, homogeneous iron catalysts in the presence of reactive substrates such as azides, were employed for the room temperature amination of challenging $\mathrm{C}\left(\mathrm{sp}^{3}\right)-\mathrm{H}$ bonds, involving azide cyclization and iron-bound pyrrolidine products. ${ }^{[70]}$ In this sense, Wembin Lin and co-workers developed an effective strategy for the post-synthesis installation of diamine ligands in a porous $\mathrm{Zr}$ MOF. ${ }^{[71]}$ Its further metalation with Fe catalytic sites and subsequent activation with methyl lithium, generates the desired MOF-immobilized monoanionic ligated metal complex. The resulting $\mathrm{Fe}-\mathrm{UiO}$ heterogeneous catalyst promotes the intramolecular $\mathrm{C}\left(\mathrm{sp}^{3}\right)-\mathrm{H}$ amination of alkyl azides. This MOF was even more active $(\mathrm{TON}=25)$ than the corresponding homogeneous catalyst (TON =6) in the synthesis of biologically active oxazolines, due to the isolation of the iron sites, avoiding its self-deactivation during the formation of a stable hexazene-bridged Fe(II) intermediate (see Fig. 15 left). The MOF catalyst was recycled and reused without a noticeable decrease in the Boc-protected $\mathrm{N}$-heterocycle yield and without appreciable metal leaching.

In section 3.4 it was mentioned how metalloporphyrins are able to catalyze the $\mathrm{C}\left(\mathrm{sp}^{2}\right)-\mathrm{H}$ bond functionalization of indoles by $\mathrm{C}-\mathrm{H}$ carbene insertion (see Fig. 13, right). Frances Arnold and co-workers reported the directed evolution of an iron-containing cytochrome P450 monooxygenase, as catalyst for the highly enantioselective intermolecular amination of benzylic $\mathrm{C}\left(\mathrm{sp}^{3}\right)-\mathrm{H}$ bonds. ${ }^{[72]}$ This biocatalyst was capable of up to 1300 turnovers, exhibiting excellent enantioselectivities to valuable benzylic amines containing the pharmaceutically relevant sulfonamide group. Interestingly, the evolved enzyme's protein framework confers activity on an otherwise unreactive iron-haem cofactor. Reaction of the aminating reagent, tosylazide, with the ferrous porphyrin generates an enzyme-bound iron nitrenoid intermediate that is inserted into a $\mathrm{C}-\mathrm{H}$ bond of the alkane, generating the benzylic amine (see Fig. 15 right).

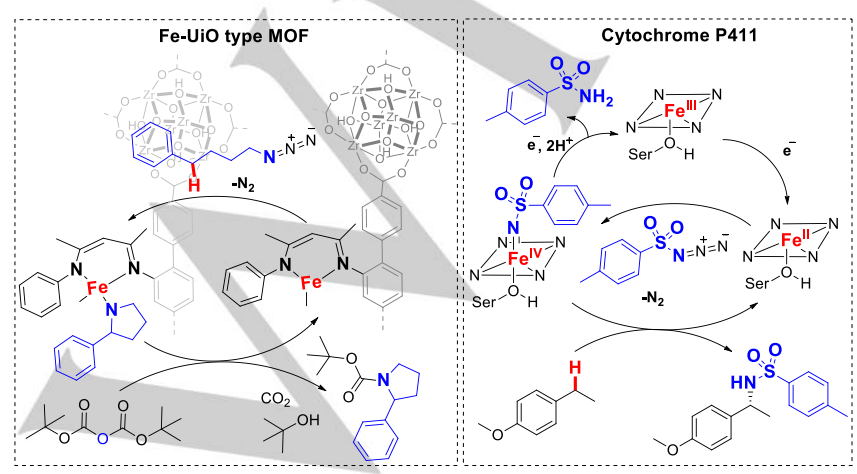

Figure 15. Proposed mechanism of Fe-UiO (left) or cytochrome P411 (right) catalyzed $\mathrm{C}-\mathrm{H}$ amination.
Beside pyrrolidines and sulfonamides, enantioriched amino alcohols are biologically important compounds that can be obtained by one-pot asymmetric sequential reactions, such as epoxidation of alkenes followed by ring-opening of the epoxide with amines. Yong $\mathrm{Cui}$ and co-workers studied the catalytic performance of bimetallic $\mathrm{Mn}$ or $\mathrm{Cr}$ (salen) based chiral MOFs for the oxidation of 2,2-dimethyl-2H-chromene at the $\mathrm{Mn}^{2+}$ sites, followed by ring opening at the $\mathrm{Cr}^{3+}$ sites, using aniline as nucleophile. The close proximity of the metallic active sites (at the enantiopure metallosalen-based linkers) allow the bimetallic cooperative activation, leading to improved chemical activity and enantioselectivity. ${ }^{[73 a, b]}$ Engineered recombinant $E$. coli cells without any additional $\mathrm{NAD}^{+}$cofactor, were employed to obtain the $(S)-\beta$-amino alcohols in good to excellent conversion (> 80\%) and > $97 \%$ e.e. ${ }^{[73 c]}$ The one-pot three-step cascade includes (i) the hydrolysis of a racemic epoxide to a vicinal diol, (ii) the oxidation of the vicinal diol intermediate to an $\alpha$-hydroxy ketone and (iii) the asymmetric reductive amination of an $\alpha$ hydroxy ketone intermediate to an enantiopure $\beta$-amino alcohol.

A final example of $\mathrm{C}-\mathrm{N}$ bond formation is the click reaction or 1,3-dipolar cycloaddition of azides and alkynes to form bio-active 1,4-disubstituted triazoles. One-pot two-step processes starting from alkynes, haloalkanes (or epoxides) and sodium azide are reported using MOFs (or enzymes) as catalysts. On the one hand, the Zr-UiO MOF illustrated in the left part of Fig. 15 was employed as support of $\mathrm{Cu}(\mathrm{I})$ active sites for the tandem azidation of benzyl chloride and further cycloaddition with phenylacetylene in water at $80{ }^{\circ} \mathrm{C}$, resulting in excellent triazole yields (>99\% after $8 \mathrm{~h}$ ) but no stereoselectivity. ${ }^{[7]}$ On the other hand, the enzyme halohydrin dehalogenase catalyzed the enantioselective azidolysis of aromatic epoxides to 1,2-azido alcohols, which subsequently suffer a copper-free cycloaddition with cyclooctine. This room temperature, metal-free, one-pot cascade, produces chiral hydroxy triazoles with moderate conversion (32\% after $48 \mathrm{~h})$ but excellent enantiomeric excess $(96 \%) .{ }^{[75]}$

\section{Conclusions and Outlook}

MOF design and synthesis as catalyst in organic transformations started just a few years ago, aiming at cost-efficient synthetic methodologies for the production of value-added molecules. In contrast, enzymes have been optimizing their skills to transform its natural substrates for more than $3 \times 10^{9}$ years, being only widely applied as catalysts in organic synthesis since the beginning of this century. However, this natural evolution is now speed up through the use of biotechnology (directed evolution), designing enzymes with enhanced stabilities and altered (stereo)specificities within a few months, able to catalyze new reactions for which they were not naturally employed. In this work, some of these examples are reviewed: artificial retroaldolase for Knoevenagel condensations (section 3.1), promiscuous hydroxynitrile lyase for Henry reactions (section 
3.2), promiscuous lipase for Michael additions (section 3.3), engineered tryptophan synthase for Friedel-Crafts alkylations (section 3.4), engineered $\beta$-lyase for hydroaminations (section 4.1) or mutant cytochrome P450 for oxidative aminations (section 4.2). All these engineered enzymes have been compared with engineered MOF catalysts in the synthesis of several APIs (see structures 1-8) through $\mathrm{C}-\mathrm{C} / \mathrm{C}-\mathrm{N}$ bond formations.

This mini review shows how the versatile design of MOFs, often allows for the simultaneous introduction of several active sites as multifunctional catalysts. On the contrary, the use of pure multi-enzymatic complexes or the combination of bio- and chemo- catalysis, is more challenging (when scaling up is foreseen) due to stability issues. ${ }^{[76]}$ In addition, pioneering and structured efforts to design and synthesize chiral MOFs, ${ }^{[59,73]}$ encourages further research to compete with highly stereoselective biocatalysts, as can be deduced from the excellent performance of (promiscuous) aldolases and lyases reviewed here (sections 3.2 and 3.3). The use of robust and stereoselective MOF type materials will definitively facilitate the regeneration and recycle of the catalyst, an advantage with respect to enzymes in the synthesis of chiral molecules. ${ }^{[77]}$

Despite from the fact that both MOFs and enzymes are relatively expensive materials, their cost is justified based on the high added value of the pharmaceuticals synthesized and by the fact that these catalysts may be reused in various reaction cycles without altering their catalytic performance. In the case of MOFs, the use of earth abundant biocompatible metals, such as $\mathrm{Zn}$ or $\mathrm{Cu}$, is preferred over precious and/or toxic metals. Although the commercial prices of the MOF organic linkers are expensive, there are well-established synthetic processes to easily produce standard MOF linkers from more cheap and available starting products, decreasing the linker cost in about two orders of magnitude. ${ }^{[78]}$ The synthetic cost of the MOF also decreases to the half when using water as solvent and it is expected that its industrial production will cost even less than $100 € / \mathrm{kg}^{\left[{ }^{[79]} \text { Despite }\right.}$ from the fact that less expensive metals and synthetic procedures to obtain MOF linkers are on high demand, the price of state-of-the-art MOFs are nowadays as expensive as those of crude enzymes. ${ }^{[80]}$ It is expected that MOFs and enzymes might be "benign by design" in the next future, being produced from readily available renewable resources (biomass derived organic molecules for MOF linkers or microorganisms for enzymes), which will contribute to the cost-efficient and competitive organic synthesis of high quality but affordable key active pharmaceutical ingredients.

\section{Acknowledgements}

The European Commission-Horizon 2020 is acknowledged for funding through a Marie Sklodowska Curie Individual Fellowship under the grant agreement number 750391 (SINMOF).

Keywords: Organic synthesis • Heterogeneous catalysts • Enzyme mimics $•$ Pharmaceuticals $\cdot$ MOFs
[1] https://esa.un.org/unpd/wpp/Graphs/DemographicProfiles/

[2] H. C. Erythropel, J. B. Zimmerman, T. M. de Winter, L. Petitjean, F. Melnikov, C. Ho Lam, A. W. Lounsbury, K. E. Mellor, N. Z. Janković, Q. Tu, L. N. Pincus, M. M. Falinski, W. Shi, P. Coish, D. L. Plata, P. T Anastas, Green Chem. 2018, 20, 1929-1961.

[3] C. A. Busacca, D. R. Fandrick, J. J. Song, C. H. Senanayakea, Adv. Synth. Catal. 2011, 353, 1825-1864.

[4] R. A. Sheldon, Green Chem. 2017, 19, 18-43.

[5] (a) M. D. Truppo, ACS Med. Chem. Lett. 2017, 8, 476-480; (b) F. Rudroff, M. D. Mihovilovic, H. Gröger, R. Snajdrova, H. Iding, U. T. Bornscheuer, Nature Cat. 2018, 1, 12-22; (b) R. A. Sheldon, J. M Woodley, Chem. Rev. 2018, 118, 801-838.

[6] K. Faber in Biotransformations in Organic Chemistry, Springer, Berlin, 2017, pp. 1-30.

[7] (a) F. Schwizer, Y. Okamoto, T. Heinisch, Y. Gu, M. M. Pellizzoni, V Lebrun, R. Reuter, V. Kohler, J. C. Lewis, T. R. Ward, Chem. Rev. 2018, 118, 142-231; (b) Z. Dong, Q. Luo, J. Liu, Chem. Soc. Rev. 2012, 41, 7890-7908.

[8] M. Beller, Ernst Schering Found Symp Proc. 2006, 99-116.

[9] H.-U. Blaser, Catal. Today 2000, 60, 161-165

[10] R. Porta, M. Benaglia, A. Puglisi, Org. Process. Res. Dev. 2016, 20, 2 25.

[11] (a) J. Jiang, Y. Zhao, O. M. Yaghi, J. Am. Chem. Soc. 2016, 138, 32553265; (b) F. G. Cirujano, Catal. Sci. Technol. 2017, 7, 5482-5494.

[12] (a) I. Nath, J. Chakraborty, Francis Verpoort, Chem. Soc. Rev 2016, 45 4127-4170; (b) Y. Chen, S. Ma, Dalton Trans. 2016, 45, 9744-9753; (c) A. M. Fracaroli, P. Simon, D. A. Nagib, M. Suzuki, H. Furukawa, F. D. Toste, Coord. Chem. Rev. 2019, 378, 445-465.

[13] (a) F. G. Cirujano, F. X. Labres i Xamena in Organic Nanoreactors (Ed.: S. Sadjadi), Elsevier, 2016, pp. 305-340; (b) F. Llabrés i Xamena, I. Luz, F. G. Cirujano in Metal Organic Frameworks as Heterogeneous Catalysts (Eds. F. L. Xamena, J. Gascon), RSC, 2013, pp. 237-267.

[14] R. Gamsjaeger, C. K. Liew, F. E. Loughlin, M. Crossley, J. P. Mackay, Trends Biochem. Sci. 2017, 32, 63-70.

[15] M. D. Allendorf, V. Stavila, CrystEngComm 2015, 17, 229-246.

[16] C. Kutzscher, G. Nickerl, I. Senkovska, V. Bon, S. Kaskel, Chem. Mater. 2016, 28, 2573-2580.

[17] V. Pandyarajan, M. A. Weiss, Curr. Diab. Rep. 2012, 12, 697-704.

[18] (a) D. Fairen-Jimenez, S. A. Moggach, M. T. Wharmby, P. A. Wright, S. Parsons, T. Düren, J. Am. Chem. Soc. 2011, 133, 8900-8902; (b) C Chizallet, S. Lazare, D. Bazer-Bachi, F. Bonnier, V. Lecocq, E. Soyer, A.-A. Quoineaud, N. Bats, J. Am. Chem. Soc. 2010, 132, 12365-12377; (c) U. P. N. Tran, K. K. A. Le, N. T. S. Phan, ACS Catal. 2011, 1, 120127; (d) L. Chen, B. Duan, Q. Luo, Z. Gu, J. Liua, C. Duan, Catal. Sci. Technol. 2016, 6, 1616-1620; (e) B. Murillo, B. Zornoza, O. De La Iglesia, C. Téllez, J. Coronas, J. Catal. 2016, 334, 60-67; (f) S. Chaemchuen, Z. Luo, K. Zhou, B. Mousavia, S. Phatanasri, M. Jaroniec, F. Verpoort, J. Catal. 2017, 354, 84-91; (g) B. Mousavi, Z. Luo, S. Phatanasri, W. Su, T. Wang, S. Chaemchuen, F. Verpoort, Eur. J. Inorg. Chem. 2017, 42, 4947-4954.

[19] W. Maret, Y. Li, Chem. Rev. 2009, 109, 4682-4707.

[20] B. L. Vallee, D. S. Auld, Acc. Chem. Res. 1993, 26, 543-551.

[21] M. Brovetto, D. Gamenara, P. Saenz Mendez, G. A. Seoane, Chem. Rev. 2011, 111, 4346-4403.

[22] E. Knoevenagel, Ber. De. Chem. Ges. 1898, 31, 2596-2619.

[23] P. Valvekens, M. Vandichel, M. Waroquier, V. Van Speybroeck, D. De Vos, J. Catal. 2014, 317, 1-10.

[24] J. Gascon, U. Aktay, M. Hernandez-Alonso, G. Vanklink, F. Kapteijn, J. Catal. 2009, 261, 75-87.

[25] (a) W. Kemnitzer, J. Drewe, S. Jiang, H. Zhang, C. Crogan-Grundy, D. Labreque, M. Bubenick, G. Attardo, R. Denis, S. Lamothe, H. Gourdeau, B. Tseng, S. Kasibhatla, S. X. Cai, J. Med. Chem. 2008, 51, 417-423; (b) S. Rostamnia, A. Morsali, Inorg. Chim. Acta 2014, 411, 113-118. 
[26] (a) K. S. Atwal, B. N. Swanson, S. E. Unger, D. M. Floyd, S. Moreland A. Hedberg, B. C. O'Reilly, J. Med. Chem. 1991, 34, 806-811; (b) S Rostamnia, A. Morsali, RSC Adv. 2014, 4, 10514-10518.

[27] R. Cortese, D. Duca, Phys. Chem. Chem. Phys. 2011, 13, 15995 16004.

[28] W. Hu, Z. Guan, X. Deng, Y.-H. He, Biochimie 2012, 94, 656-661.

[29] X. Garrabou, B. I. M. Wicky, D. Hilvert, J. Am. Chem. Soc. 2016, 138, 6972-6974.

[30] L. Henry, Comptes Rendus. 1895, 120, 1265-1268.

[31] Y. Zhou, J. Dong, F. Zhang, Y. Gong, J. Org. Chem. 2011, 76, 588-600.

[32] K. M. Brown, K. K. Roy, G. H. Hockerman, R. J. Doerksen, D. A. Colby, J. Med. Chem. 2015, 58, 6336-6347.

[33] F. G. Cirujano, E Lopez-Maya, M. Rodriguez-Albelo, E. Barea, J. A. R. Navarro, D. E. De Vos, ChemCatChem. 2017, 9, 4019-4023.

[34] J. Zuegg, K. Gruber, M. Gugganig, U. G. Wagner, C. Kratky, Protein Sci. 1999, 8, 1990-2000.

[35] (a) T. Purkarthofer, K. Gruber, M. Gruber-Khadjawi, K. Waich, W. Skranc, D. Mink, H. Griengl, Angew. Chem. Int. Ed. 2006, 45, 34543456; (b) M. Bekerle-Bogner, M. Gruber-Khadjawi, H. Wiltsche, R Wiedner, H. Schwab, K. Steiner, ChemCatChem. 2016, 8, 2214-2216.

[36] X. Garrabou, D. S. Macdonald, D. Hilvert, Chem. Eur. J. 2017, 23, 6001-6003.

[37] (a) P. W. Siu, Z. J. Brown, O. K. Farha, J. T. Hupp, K. A. Scheidt, Chem. Commun. 2013, 49, 10920-10922; (b) Y. Fan, Y. Ren, J. Li, C. Yue, H. Jiang, Inorg. Chem. 2018, 57, 11986-11994

[38] (a) A. M. Klibanov, Nature 2001, 409, 241-246; (b) J. Navarro, N Almora-Barrios, B. Lerma-Berlanga, J. J. Ruiz-Pernía, V. A. LorenzFonfria, I. Tuñón, C. Martí-Gastaldo, Chem. Sci. 2019, DOI 10.1039/C9SC00082H; (c) X. Lian, Y. Fang, E. Joseph, Q. Wang, J. Li, S. Banerjee, C. Lollar, X. Wang, H. C. Zhou, Chem. Soc. Rev. 2017, 46 3386-3401; (d) C. Doonan, R. Ricco, K. Liang, D. Bradshaw, P. Falcaro, Acc. Chem. Res. 2017, 50, 1423-1432; (e) E. Gkaniatsou, C. Sicard, R Ricoux, J.-P. Mahy, N. Steunou, C. Serre, Mater. Horiz. 2017, 4, 55-63 (f) S. M. F. Vilela, P. Horcajada in Metal-Organic Frameworks, (Eds. H. García, S. Navalón), Wiley-VCH, 2018, 447-476; (g) R. J. Drout, L. Robison, O. K. Farha, Coord. Chem. Rev. 2019, 381, 151-160.

[39] A. Michael, Prakt. Chem. 1887, 35, 349-356.

[40] (a) K. D. Hargrave, C. K. Miao, WO9806719; (b) K. I. Chung, J. E. Lee WO2004046081; (c) A. G. Thakur, M. P. Kulkarni, WO2013103967.

[41] (a) Y. Miao, M. Rahimi, E. M Geertsema, G. J Poelarends, Curr. Opin. Chem. Bio. 2015, 25, 115-123; (b) L. Zhu, X.-Q. Liu, H.-L. Jiang, L.-B. Sun, Chem. Rev. 2017, 117, 8129-8176.

[42] A. Y. Sukhorukov, A. A. Sukhanova, S. G. Zlotin, Tetrahedron 2016, 72, 6191-6281.

[43] W. M. Barker, M. A. Hermodson, K. P. Link, J. Med. Chem. 1971, 14, 167-169.

[44] (a) B.-H. Xie, Z. Guan, Y.-H. He, J. Chem. Technol. Biotechnol. 2012, 87, 1709-1714; (b) K. Sano, S. I. Saito, Y. Hirose, Y. Kohari, H. Nakano C. Seki, M. Tokiwa, M. Takeshita, K. Uwai, Heterocycles 2013, 87, 1269-1278.

[45] M. Svedendahl, K. Hult, P. Berglund, J. Am. Chem. Soc. 2005, 127, 17988-17989.

[46] W.-L. Liu, N.-S. Yang, Y.-T. Chen, S. Lirio, C.-Y. Wu, C.-H. Lin, H.-Y. Huang, Chem. Eur. J. 2015, 21, 115-119.

[47] T. Shi, Z. Guo, H. Yu, J. Xie, Y. Zhong, W. Zhua, Adv. Synth. Catal. 2013, 355, 2538-2543.

[48] (a) C. Friedel, J. M. Crafts, C. R. Hebd. Seances Acad. Sci. 1877, 84, 1392; (b) Friedel, J. M. Crafts, C. R. Hebd. Seances Acad. Sci. 1877 84, 1450.

[49] G. Spadoni, B. Stankov, A. Duranti, G. Biella, V. Lucini, A. Salvatori, F. Fraschini, J. Med. Chem. 1993, 36, 4069-4074.

[50] M. Somei, Heterocycles 1999, 50,1157-1211.

[51] N. Martin, M. Dusselier, D. E. De Vos, F. G. Cirujano, ACS Catal. 2019, 9, 44-48.
[52] K. Tanaka, K. Sakuragi, H. Ozaki and Y. Takada, Chem. Commun., 2018, 54, 6328-6331.

[53] F. G. Cirujano, M. Stalpaert, D. E. De Vos, Green Chem. 2018, 20 , 2481-2485.

[54] A. R. Buller, P. van Roye, J. K. B. Cahn, R. Scheele, M. Herger, F. H. Arnold, J. Am. Chem. Soc. 2018, 140, 7256-7266.

[55] I. Moritani, Y. Fujiwara, Tetrahedron Lett. 1967, 8, 1119-1122.

[56] F. G. Cirujano, P. Leo, J. Vercammen, S. Smolders, G. Orcajo, D. E. De Vos, Adv. Synth. Catal. 2018, 360, 3872-3876.

[57] (a) F. R. Fortea-Pérez, M. Mon, J. Ferrando-Soria J, M. Boronat, A. Leyva-Pérez, A. Corma, J. M. Herrera, D. Osadchii, J. Gascon, D. Armentano, E. Pardo, Nat. Mater. 2017, 16, 760-766; (b) Z- J. Wang, H. Renata, N. E. Peck, C. C. Farwell, P. S. Coelho, F. H. Arnold, Angew. Chem. Int. Ed. 2014, 53, 6810-6813.

[58] D. A. Vargas, A. Tinoco, V. Tyagi, R. Fasan, Angew. Chem. Int. Ed. 2018, 57, 9911-9915.

[59] (a) M. Zheng, Y. Liu, C. Wang, S. Liu, W. Lin Chem. Sci. 2012, 3, 2623-2627; (b) X. Chen, H. Jiang, B. Hou, W. Gong, Y. Liu, Y. Cui, J. Am. Chem. Soc. 2017, 139, 13476-13482.

[60] W. Howke, I. Littles, I. Scott, G. M. Whitman, J. Am. Chem. Soc. 1954 76, 1899-1902.

[61] Mark R. Crimmin, Ian J. Casely, M. S. Hill, J. Am. Chem. Soc. 2005, 127, 2042-2043

[62] (a) K. Manna, P. Ji, F. X. Greene, W. Lin, J. Am. Chem. Soc. 2016, 138, 7488-7491; (b) T. Sawano, N. C. Thacker, Z. Lin, A. R. Mclsaac, W. Lin, J. Am. Chem. Soc. 2015, 137, 12241-12248.

[63] (a) Y. J. Wu, H. He, J. J. Bronson, US7138423; (b) C. Bissantz, T. Hoffmann, P. Jablonski, H. Knust, M. Nettekoven, R. Ratni, US7893062.

[64] A. Klapars, K. R. Campos, J. H. Waldman, D. Zewge, P. G. Dormer, C.yi Chen, J. Org. Chem. 2008, 73, 4986-4993.

[65] E. W. Stern, M. L. Spector, Proc. Chem. Soc. 1961, 0, 357-396.

[66] B. R. Reiner, N. T. Mucha, A. Rothstein, J. S. Temme, P. Duan, K. Schmidt-Rohr, B. M. Foxman, C. R. Wade, Inorg. Chem. 2018, 57, 2663-2672

[67] F. G. Cirujano, E. López-Maya, J. A. R. Navarro, D. E. De Vos, Top. Catal. 2018, 61, 1414-1423.

[68] (a) R. Li, H. J. Wijma, L. Song, Y. Cui, M. Otzen, Y. Tian, J. Du, T. Li, D. Niu, Y. Chen, J. Feng, J. Han, H. Chen, Y. Tao, D. B. Janssen, B. Wu, Nat. Chem. Biol. 2018, 14, 664-670; (b) S. T. Ahmed, F. Parmeggiani, N. J. Weise, S. L. Flitsch, N. J. Turner, ACS Catal. 2018, 8, 3129-3132.

[69] L. S. Hegedus, G. F. Allen, J. J. Bozell, E. L. Waterman, J. Am. Chem. Soc. 1978, 100, 5800-5807.

[70] E. T. Hennessy, T. A. Betley, Science 2013, 340, 591-595.

[71] N. C. Thacker, Z. Lin, T. Zhang, J. C. Gilhula, C. W. Abney, W. Lin, J. Am. Chem. Soc. 2016, 138, 3501-3509.

[72] C. K. Prier, R. K. Zhang, A. R. Buller, S. B. Chen, F. H. Arnold, Nat. Chem. 2017, 9, 629-634.

[73] (a) Q. Xia, Z. Li, C. Tan, Y. Liu, W. Gong, Y. Cui, J. Am. Chem. Soc 2017, 139, 8259-8266; (b) C. Tan, X. Han, Z. Li, Y. Liu, Y. Cui, J. Am Chem. Soc. 2018, 140, 16229-16236; (c) J.-D. Zhang, X.-X. Yang, Q. Jia, J.-W. Zhao, L.-L. Gao, W.-C. Gao, H.-H. Chang, W.-L. Wei, J.-H. Xu, Catal. Sci. Technol. 2019, 9, 70-74.

[74] Y.-H. Hu, J.-C. Wang, S. Yang, Y.-A. Li, Y.-B. Dong, Inorg. Chem. 2017, 56, 8341-8347.

[75] L. S. Campbell-Verduyn, W. Szymanski, C. P. Postema, R. A. Dierckx, P. H. Elsinga, D. B. Janssen, B. L. Feringa, Chem. Commun. 2010, 46, 898-900.

[76] (a) T. Sehl, H. C. Hailes, J. M. Ward, R. Wardenga, E. von Lieres, H Offermann, R. Westphal, M. Pohl, D. Rother, Angew. Chem. Int. Ed. 2013, 52, 6772-6775; (b) F. Rudroff, M. D. Mihovilovic, H. Gröger, R Snajdrova, H. Iding, U. T. Bornscheuer, Nat. Catal. 2018, 1, 12-22.

[77] L. Ma, C. Abneya, W. Lin, Chem. Soc. Rev. 2009, 38, 1248-1256.

[78] (a) A. Bhattacharyya, J. T. Walenga, US8933266B2; (b). D. J. Sikkema, A. M. Reichwein, US6040478A. 
[79] (a) D. DeSantis, J. A. Mason, B. D. James, C. Houchins, J. R. Long, M. Veenstra, Energy Fuels 2017, 31, 2024-2032; (b) B. Karadeniz, A. J. Howarth, T. Stolar, T. Islamoglu, I. Dejanovic, M. Tireli, M. C. Wasson, S. Y. Moon, O. K. Farha, K. Uzarevic, ACS Sust. Chem. Eng. 2018, 6, 15841-15849.

[80] (a) P. Tufvesson, J. Lima-Ramos, M. Nordblad, J. M. Woodley, Org. Process. Res. Dev. 2011, 15, 266-274; (b) L. F. Bugada, M. R. Smith, F. Wen, ACS Catal. 2018, 8, 7898-7906. 
Entry for the Table of Contents (Please choose one layout)

Layout 1:

\section{MINIREVIEW}

Engineered enzymes and MOFs are compared as novel catalysts in the organic synthesis of interesting scaffolds in the context of cost-efficient pharmaceutical processes.
Author(s), Corresponding Author(s)*

Page No. - Page No.

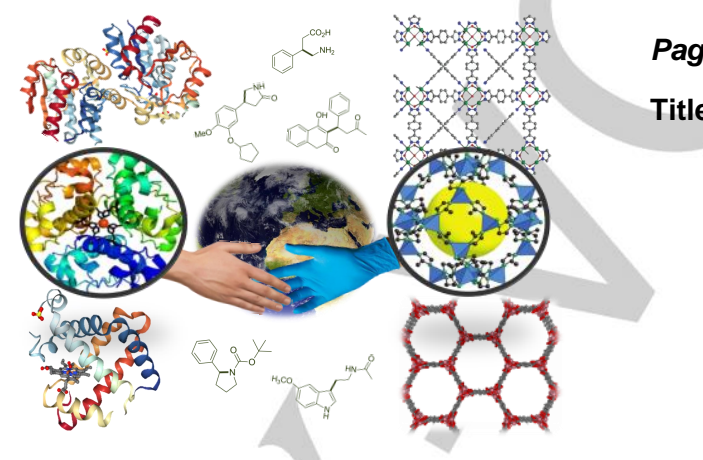

Title 